DOI: $10.12797 /$ Politeja.12.2015.35.17

Katarzyna ŻAKIETA

Uniwersytet Łódzki

zakieta.katarzyna@gmail.com

\title{
PAMIĘĆ, TABU, TRAUMA W NAJNOWSZYM KINIE POLSKIM
}

\author{
PRZYPADEK RÓŻY W. SMARZOWSKIEGO, \\ IDY P. PAWLIKOWSKIEGO \\ I POKŁOSIA W. PASIKOWSKIEGO
}

\section{ABSTRACT Memory, Taboo, Trauma in Contemporary Polish Cinema}

Contemporary film settlement of the twentieth-century history, especially of experiences of World War II and Polish People's Republic, on the one hand continues the tradition started by Polish Film School of de-mythologizing trend, on the other hand - seeks new means of aesthetic expression. Through the analysis of Rose, dir. W. Smarzowski, Aftermath, dir. W. Pasikowski and Ida, dir. P. Pawlikowski, I present how the recent Polish cinema struggles with the collective trauma. As my research tools, I used concepts proposed by M. Hirsch, J.K. Olick, D. LaCapra and A. Landsberg, among others. That allowed me to take a look at relations between the protagonists inside diegesis, but also to reflect on the situation of the Polish cinema, which still struggles with, what M. Janion defined as "the post-Romantic neurosis of Polish society". However, I have tried to show, that "the politics of regret", "the prosthetic memory" and, dictated by the logic of capitalism, the realities of postmemory in popular culture, may have also positive overtones in highlighting marginalised history.

Key-words: Róża (Rose), Ida, Poktosie (Aftermath), prosthetic memory, postmemory, politics of regret

Słowa kluczowe: Róża, Ida, Poktosie, pamięć protetyczna, postpamięć, polityka żalu 
R efleksję na temat polskich filmów poruszających tematykę pamięci i traumy chciaRabym poprowadzić dwutorowo. $Z$ jednej strony pragnę zwrócić uwagę na to, w jaki sposób doświadczenie lub pamięć wojennych wydarzeń prezentowane są na ekranie za pomocą typowych dla medium filmowego środków, a więc pozostać w obszarze samego tekstu. $Z$ drugiej zaś w przypadku poruszanego zagadnienia trudno nie odwołać się do kontekstu historycznego, społecznego, politycznego oraz do kwestii związanych z recepcją obrazów, które dotykają obszarów tabuizowanych. Ich odbiór nie ogranicza się do wewnętrznych przeżyć jednostki, wykracza poza sale kinowe oraz domowe zacisze. Coraz częściej rozpoczyna debatę publiczną o różnym stopniu nasilenia. Co w takim razie odpowiada za ożywioną dyskusję w mediach i niegasnącą popularność filmowych reprezentacji bezpośrednio lub pośrednio mówiących o wydarzeniach II wojny światowej?

\section{PAMIĘĆ WOJNY - WYMAZYWANIE I MANIPULACJA}

Rozpocznę od pewnej truistycznej, acz koniecznej uwagi dotyczącej nie tylko historii kina polskiego, ale także społecznej świadomości. Lata 1939-1945 odcisnęły głębokie piętno na całej ludzkości, w tym również na mieszkańcach Polski. Tematyka wojenna w kinie była głównym tematem poruszanym przez twórców związanych z Polską Szkołą Filmową (ok. 1955-1962)1, jednak należy zauważyć, że wszyscy ci reżyserzy mieli bezpośredni kontakt z wojną, która była wpleciona w ich biografie. Owo doświadczenie domagało się wyartykułowania, co zresztą dotyczyło całego społeczeństwa, które twórczość Szkoły Polskiej (m.in. Andrzeja Munka, Andrzeja Wajdy, Wojciecha Jerzego Hasa) zdecydowanie doceniało i akceptowało. Nie bez znaczenia jest tu właśnie kontekst traumy. Nie chcę się zagłębiać w psychoanalityczne aspekty procesu twórczego, ponieważ nie będą mnie interesowały biografie konkretnych reżyserów. Jednak w kontekście powyższych spostrzeżeń wypada wspomnieć, że jedną z pierwszych zauważonych na gruncie psychologii nerwic była właśnie nerwica frontowa czy też inaczej - wojenna, która objawiała się pourazowym zespołem stresu, co zauważono jeszcze w XIX w. ${ }^{2}$ Twórcy Polskiej Szkoły Filmowej ukształtowani przez wojenne realia i przemianę ustrojową nawiązywali silny emocjonalny kontakt z publicznością dzielącą ich doświadczenie, będącą ofiarami i świadkami. Niestety sama społeczna potrzeba mówienia o wojnie nie wystarczyła do swobodnego przepływu informacji. Zanim w połowie lat 50. nadeszła odwilż, a twórcy Szkoły Polskiej mogli zabrać głos, w rodzimym filmie podjęto pierwsze próby ukazania wojennej traumy. Niestety, w większości zostały one zablokowane przez rozpoczynającą swą działalność cenzurę.

Zob.: T. Lubelski, Historia kina polskiego. Twórcy, filmy, konteksty, Katowice 2009, s. 157-221.

A. Radny, Wptyw traumy na psychikę. Psychoterapia ofiary, „Annales Academiae Medicae Stetinentis” 2011, sympozja 1: Neurokognitywistyka w patologii i zdrowiu 2009-2011, s. 107-108. 
Tuż po wojnie starano się pokazać skomplikowane perypetie wojenne nie tylko na przykładzie Polaków. Zanim w 1949 r. oficjalnie proklamowano socrealizm jako jedyną możliwą metodę twórczą, Aleksander Ford wyreżyserował fabularny film Ulica Graniczna (1948), który jest całkiem odmienny niż paradokumentalny Ostatni etap (1947) Wandy Jakubowskiej. Reżyserka skupiła się na bohaterze kolektywnym i na internacjonalizacji Zagłady ${ }^{3}$. Los Żydów w Ostatnim etapie nie jest wyróżniany, zostaje wtopiony w pozbawioną podziałów narodowościowych zbrodnię przeciw ludzkości i tym samym rozpoczyna, kontynuowaną później przez władzę ludową, politykę, w której polonizuje się Szoa ${ }^{4}$. Ford natomiast pokazuje grupę zamieszkującą jedną kamienicę, ale na jej tle wyraźnie odcinają się indywidualne biografie, a nawet indywidualne tożsamości. Akcja filmu rozpoczyna się wraz z wybuchem wojny i wprost pokazuje trudne relacje polsko-żydowskie. Niestety, mimo przeniesienia produkcji do Czechosłowacji cenzura miała znaczący wpływ na finalny kształt utworu ${ }^{5}$. Reżyserowi nie pozwolono na poprowadzenie postaci w sposób, który uwypuklałby żydowską tragedię. W pierwowzorze Dawidek - żydowski chtopiec ginąt podczas ucieczki z ptonacego getta, a Jadzia - dziewczynka, która odkrywa swe pochodzenie w momencie, gdy tworzone jest getto - z ręki Fredka [volksdeutscha] $]^{6}$ W dystrybuowanej wersji dziecięcy protagoniści mają szansę na ratunek, Fredek (czyli najbardziej negatywna postać) zostaje zabity, a reszta bohaterów z czasem zmienia zdanie na temat Żydów, toteż polska moralność nie zostaje nadszarpnięta. Po premierze film Forda i tak został skrytykowany za zbyt odważne podjęcie tematu, a władze postanowiły znacznie zaostrzyć restrykcje względem ukazywania zindywidualizowanych bohaterów o odmiennej tożsamości narodowej. Na fali obostrzeń nie pozwolono zrealizować Jerzemu Zarzyckiemu pierwszej wersji Robinsona warszawskiego, opartej na rozmowach z ocalałym Władysławem Szpilmanem. W ostatecznej wersji filmu, pt. Miasto nieujarzmione (1950), wyeksponowano wspólne, bohaterskie działania armii polskiej i radzieckiej. Światła dziennego nie ujrzał także projekt Ludwika Perskiego o Januszu Korczaku ${ }^{7}$ Do połowy lat 50. obraz wojny wyłaniający się z polskich filmów fabularnych był zafałszowany i zdominowany przez oficjalną politykę.

W tym kontekście można przytoczyć inspirowane Pierre'em Bourdieau rozważana Jeffreya K. Olicka, socjologa z Uniwersytetu Virginii zajmującego się pamięcią kolektywną oraz powojenną historią Niemiec, który mówi o wpływie władzy na pamięć zbiorową poprzez „przemoc kulturową". W owym czasie strona radziecka doskonale wykorzystywała przemoc symboliczną w budowaniu podległej społeczności. Obecnie bardzo często różne państwa (także Polska) posługują się tego rodzaju perswazyjnym

3 K. Mąka-Malatyńska, Widok z tej strony. Przedstawienia Holocaustu w polskim filmie, Poznań 2012, s. 19-20, Seria Filmoznawcza, nr 9.

\section{Tamże.}

Tamże.

Tamże.

Tamże, s. 20.

Zob.: M. Kobielska, Pamięć zbiorowa w centrum nowoczesności. Ujęcie Jeffreya K. Olicka, „Teksty Drugie" 2010, nr 6, s. 188-189. 
potencjałem w legitymizacji władzy, ale kierują nimi zgoła odmienne motywacje, do czego jeszcze powrócę w zakończeniu.

W polskim filmie dopiero po odwilży gomułkowskiej zaczynają się pojawiać trudne pytania, demitologizacje działań i postaw. Jednak nie od razu po Październiku 1956 filmowcy podjęli tematy do tej pory ukrywane. Dopiero początek lat 60., ze względu na rozpoczęcie i nagłośnienie medialne procesu Adolfa Eichmanna oraz innych zbrodniarzy9 , przyniósł filmy, w których pojawiają się zakazane dotychczas wątki żydowskie: nowela Kropla krwi ze Świadectwa urodzenia (1961), reż. S. Różewicz; Samson (1961), reż. A. Wajda; Ludzie z pociagu (1961), reż. K. Kutz; i przede wszystkim, nieco wcześniejszy, Biaty niedźwiedź (1959) Jerzego Zarzyckiego ${ }^{10}$, ale jak na wagę tematu, nie byto tych filmów wiele ${ }^{11}$.

Jednym z dosyć paradoksalnych aspektów budowania Polskiej Rzeczypospolitej Ludowej doby Władysława Gomułki było uświadomienie Polakom ich jedności narodowej. Ówczesne władze czyniły to poprzez utrwalenie mitu heroiczno-martyrologicznego, podkreślanie roli powstania warszawskiego i wyraźne zaznaczanie odrębności narodu polskiego na tle innych nacji, czego dowodem były narastające postawy antysemickie, które skrajną formę przyjęły w roku $1968^{12}$. Katarzyna Mąka-Malatyńska zwraca uwagę, że po okresie Szkoły Polskiej do lat 80. i silnej działalności opozycyjnej mówienie o mniejszościach odbywało się albo poprzez polonizację, albo przez silne zmetaforyzowanie treści, w znacznym stopniu utrudniające cenzorom odłożenie filmu na półkę ${ }^{13}$. Jednakże oddziaływanie cenzury niejako zmusiło polskich twórców do wytworzenia niepowtarzalnego stylu filmowego, zbudowanego wokół skomplikowanej metaforyki, za pomocą której starali się oni przemycać istotne treści. $\mathrm{O}$ ile tematyka żydowska traktowana była przez władze, w zależności od okresu, jako punkt zapalny albo „wentyl bezpieczeństwa"14 dzięki czemu mogła w ogóle zaistnieć w pamięci zbiorowej, o tyle problemy innych mniejszości - Cyganów, Mazurów czy Łemków - w filmie fabularnym nie znalazły swojego odzwierciedlenia. Wyjątkami, pokazującymi obszar Mazur tuż po 1945 r., są: Potudnik zero (1970) Waldemara Podgórskiego oraz Azyl (1978) Romana Załuskiego, ale obrazy te są silnie nasycone wątkami propagandowymi ${ }^{15}$. Ich naczelnym celem było pokazanie, że wprowadzenie nowej władzy wyszło tamtejszym mieszkańcom na dobre. Uchroniło od, postawionych w jednym rzędzie, partyzantów i rabusiów, czyhających na ich życie i mienie (Potudnik zero), ewentualnie dało szansę na zapomnienie o wojennej traumie po podporządkowaniu się nowym regułom gry $(A z y l)$. Oczywiście

K. Mąka-Malatyńska, Widok z tej strony..., s. 25.

Tamże, s. 24-25.

T. Lubelski, Historia kina polskiego..., s. 251.

A. Mach, Poetyka postpamięci i etyka świadka-spadkobiercy Zagtady w polskiej literaturze najnowszej, Warszawa 2013, s. 12-14 [maszynopis].

K. Mąka-Malatyńska, Widok z tej strony..., s. 28-33.

Tamże, s. 16.

M. Marczak, Obraz Warmii i Mazur w polskim filmie fabularnym i serialu. Rekonesans, „Media Kultura -Komunikacja Społeczna” 2012, nr 8, s. 108. 
grabieże Armii Czerwonej zostały całkowicie pominięte, podobnie jak kwestie kłopotliwej przynależności etnicznej. Z filmowych tematów zostały także wymazane: przesiedleńcza, zbrojna akcja „Wisła”, przywłaszczanie mienia żydowskiego czy eksterminacja osób homoseksualnych. Przez wieloletnie wypieranie tych wątków z historii Polski uległy one zapomnieniu, dlatego również dzisiaj odbierane są jako tabu i wzbudzają kontrowersje. Powszechność oddziaływania filmu posiada moc włączania wydarzeń historycznych w zbiorową pamięć, co postaram się rozwinąć w dalszej części pracy.

\section{PAMIĘĆ I TRAUMA W KONTEKŚCIE POLSKIEGO DOŚWIADCZENIA II WOJNY ŚWIATOWEJ}

Czy dzisiejsze polskie kino, tyle lat po wojnie, chce (a może musi) wracać do tej tematyki? Czy jest w stanie mówić o rysach na historii w inny sposób, niż utrwaliła to Szkoła Polska? Ostatnie lata dowodzą, że wojna to wciąż jeden z ważniejszych tematów. Przede wszystkim cezura roku 1989 wpłynęła na możliwość otwartego mówienia o objętych tabu wątkach polskiej historii. Sięganie do owych motywów, potrzeba mówienia o nich, przeżywanie ich „od nowa” wraz z oglądaniem filmu (lub obcowaniem z jakąkolwiek inną aktywizującą nas formą sztuki) wpisuje nas w dyskurs pamięci lub jak chciałaby to widzieć Marianne Hirsch - postpamięci i posttraumatyczności ${ }^{16}$. Joanna Tokarska-Bakir mówi, powołując się na wymienioną wyżej badaczkę, że pamięć wyrywa się [...] poza grono bezpośrednio napiętnowanych ${ }^{17}$ i nie dotyczy już tylko ofiar i ich rodzin, ma najwyraźniej charakter przemieszczenia: odbywa się w zastępczej, symbolicznej przestrzeni i czasie - w innym miejscu i ze znacznym opóźnieniem w stosunku do wydarzeń, na które się powołuje ${ }^{18}$, przedostaje się nawet do kultury masowej i w ten sposób cały czas o sobie przypomina, co prowadzi do fetyszyzacji i utowarowienia traumy: Zjawisko to wpisuje sie doskonale w horyzont "kultury posttraumatycznej” [w rozumieniu Kirby Farrell $^{19}$ - K.Ż.], rozwijajacej się gwattownie od konca lat osiemdziesiątych $w$ reakcji na wczésniejsza heroiczna „kulture milczenia”. Zadziwiając umiejętnościa godzenia obsesji na punkcie przesztości z kurcząca się świadomością historyczną, kultura posttraumatyczna skupia się wokót centralnego urazu, zadawnionego i wypartego, który niespodziewanie powraca ipoddaje rewizji cata bieżaca rzeczywistość. Formacja ta nie chce wyleczenia, raczej spetnia się w obsesyjnym wpatrywaniu w niegojaca się ranę. Uraz staje sięjej fetyszem, maska "czegoś innego", tajemnica, której sama nieświadoma, kultura ta nie potrafi inaczej zakomuni$k o w a c^{20}$. Dalej Tokarska-Bakir komentuje tezy Dominicka LaCapry, który niejako od-

16 Zob.: M. Hirsch, The Generation of Postmemory. Writing and Visual Culture After the Holocaust, New York 2012, Gender and Culture.

17 J. Tokarska-Bakir, Polska jako chory cztowiek Europy? Jedwabne, "postpamięc" $i$ historycy, [online] http://www.eurozine.com/articles/2003-05-30-tokarska-pl.html, 1 III 2014.

18 Tamże.

19 K. Farell, Post-Traumatic Culture. Injury and Interpretation in the Nineties, Baltimore 1998.

20 Tamże. 
rzuca posttraumatyczność $\mathrm{w}$ formach czysto fikcjonalnych, nieweryfikowalnych i stawia „niewzruszonego” historyka na piedestale. LaCapra odróżnia brak i utratę oraz traumę strukturalną od historycznej, krytycznie odnosi się do identyfikacji z ofiarą czy zastępczej wiktymizacji. Postuluje on natomiast postawę bardziej samoświadomą, opartą na empatii, niekoniecznie inkorporującą cudze doświadczenia ${ }^{21}$.

Mimo wszystko nie da się zaprzeczyć istnieniu w kulturze masowej, również w filmie, śladów pamięci (postpamięci), a w niektórych traumatyczności (posttraumatyczności), nie są one dziś bowiem dostępne wyłącznie naocznym świadkom czy ofiarom. Nie jestem pewna, czy wprowadzanie do terminologii przedrostka „post” jest tu niezbędne, aczkolwiek niezależnie od przyjętego nazewnictwa warto podkreślać, że pamięć nie istnieje wyłącznie w doświadczeniu indywidualnym. Może być ona przekazywana, a nawet poprzez ciągłe podkreślanie jej traumatycznych wątków posiada zdolność wpływania na kształt zbiorowej tożsamości, co LaCapra nazywa „traumą fundującą"22 i czego potwierdzenie swobodnie odnajdujemy w refleksji dotyczących dziejów Polski i jej mieszkańców. Wszystkie powstania, zabory, dwie wojny światowe utrwaliły w nas to, co Maria Janion w Niesamowitej Stowiańszczyźnie nazywa „postromantyczną neurozą społeczeństwa" ${ }^{\text {"23 }}$, która zarysowuje polskie społeczeństwo jako niezwykle podatne na rozpamiętywanie przeszłych, bolesnych wydarzeń, czym poniekąd można tłumaczyć ciągłe zainteresowanie tematyką wojenną. Anna Mach twierdzi, że Polacy jako wspólnota eliminują niechlubne, tabuizowane wątki historii ${ }^{24}$, czego najlepszym przykładem były liczne głosy sprzeciwu po premierze Poktosia. Jednak z mojej perspektywy rysuje się tu nieco odmienna sytuacja. Dzięki medialnemu nagłośnieniu konfliktu wokół kontrowersyjnej sprawy dana społeczność jest na ogromną skalę uświadamiana, a wcześniejsze przeświadczenia zostają podane w wątpliwość. Odmienna narracja o przeszłości zostaje ujawniona i wielce prawdopodobne, że chociaż przez część zbiorowości będzie zaanektowana do wspólnej pamięci. Możliwe, że jest to związane z dystansem czasowym, który umożliwił wytworzenie znacznie bardziej empatycznej postawy, lecz równie ważna jest rola filmu, który wprowadza marginalne dotąd wątki do obiegu powszechnego.

\section{TRZY FILMY, KTÓRE PORUSZYŁY POLSKĘ}

W niniejszej pracy przedstawię trzy filmy z ostatnich lat, które poruszają zagadnienie pamięci, tabu i traumy wynikające pośrednio lub bezpośrednio z kontaktu z doświadczeniem wojennym. Są to: Róża (2011) Wojciecha Smarzowskiego, Poktosie (2012)

21 Zob.: A. Szczepan, Polski dyskurs posttraumatyczny. Literatura polska ostatnich lat wobec Holokaustu itożsamościżydowskiej, [w:] Kulturapo przejściach, osoby zprzesztością. Polski dyskurspostzależnościowykonteksty i perspektywy badawcze, red. R. Nycz, Kraków 2011, s. 244-245, Seria Wydawnicza Centrum Badań Dyskursów Postzależnościowych, t. 1.

22 D. LaCapra, Historia w okresie przejściowym. Doświadczenie, tożsamość, teoria krytyczna, przeł. K. Bojarska, Kraków 2009, s. 77-78, Horyzonty Nowoczesności, t. 81.

23 M. Janion, Niesamowita Stowiańszczyzna. Fantazmaty literatury, Kraków 2006.

24 Zob.: A. Mach, Polska kondycja posttraumatyczna - próba diagnozy, [w:] Kultura po przejściach... 
Władysława Pasikowskiego oraz Ida (2013) Pawła Pawlikowskiego. Wybrałam wyżej wymienione filmy, ponieważ:

- akcja każdego z nich osadzona jest w innym czasie i cechuje ją inny dystans do wydarzeń wojennych;

- w centrum fabuły umieszczają nie jednego, lecz dwóch bohaterów;

- każdy z niech jest zupełnie inny, jeśli chodzi o użyte środki narracji i estetyki filmowej;

- we wszystkich istnieje wątek niechlubnej historii z udziałem Polaków, która dotąd była pomijana;

- wokół ich problematyki toczyła się mniej lub bardziej żarliwa dyskusja medialna, żadna z produkcji nie przeszła bez echa.

\section{RÓŻA - HOLLYWOODZKA NARRACJA Z HEROICZNYM ETOSEM?}

Róża to obraz przedstawiający sytuację Mazurów, którzy po zakończeniu wojny i zmianie granicy państwa stają się mieszkańcami Polski, ale ich odrębność etniczna powoduje liczne ataki ze strony zarówno polskiej, jak i radzieckiej. Głównymi bohaterami są Tadeusz i Róża. On - akowiec, który się nie ujawnił, ucieka po Powstaniu Warszawskim na północny wschód, szukając kryjówki przed nową władzą. Ona, samotna, pokrzywdzona, narażona na bestialstwo żołnierzy i ukrywająca córkę na poddaszu, nie chce opuścić swej rodzinnej mazurskiej ziemi. Ich losy łączą ostatnie chwile męża Róży, w których przypadkowo uczestniczy Tadeusz. Mężczyzna, przed śmiercią z ręki żołnierza Armii Czerwonej, zdąży przekazać mu obrączkę wraz ze zdjęciem oraz poprosi o przekazanie ich Róży. We wszystkich filmach Smarzowskiego centralnym punktem fabuł jest ludzkie zło, które w posępnej kolorystyce i rozdzierającej muzyce przybiera najgorszą z możliwych form. Film otwiera scena gwałtu dokonanego przez nazistów na żonie Tadeusza na gruzach dogorywającej Warszawy. Ciężko pobity nie jest w stanie uratować jej ani przed wykorzystaniem, ani przed śmiercią, a obraz ten powróci w retrospekcji jako nękające Tadeusza traumatyczne wspomnienie. Agnieszka Morstin-Popławska zaznacza, że mocna ekspozycja jest znakiem naszych czasów: Wstrzas estetyczny ma więc być naszym udziatem natychmiast po zniknięciu napisów początkowych filmu, co zreszta jest praktyką coraz częściej dziśstosowana: podobnie rozpoczyna swój film "W ciemności” Agnieszka Holland (gromada nagich kobiet pędzonych przez las do dotu śmierci); podobnie rozgrywa pierwsza scene „Sponsoringu” Matgorzata Szumowska (naturalistyczny obraz seksu za pieniądze). [...] Inna zatem obiera się dziśs metodę opowiadania o tym, co wstrzasające: zamiast stopniowego dozowania okrucieństwa i takiegoż zapoznawania nas $z$ bohaterem (jak to dawniej bywato, m.in. u Hasa), z sednem sprawy zostajemy skonfrontowani natychmiast ${ }^{25}$. Dosłowność przekazu poraża widza emocjonalnie, wybija z rytmu, nie jest powoli dozowana jak w filmach Szkoły Polskiej, lecz ata-

25 A. Morstin-Popławska, Mocne filmy i gtębokie kompleksy. „Róża” Wojtka Smarzowskiego wobec "Jak być kochanq” Wojciecha J. Hasa, „Kwartalnik Filmowy” 2012, nr 77/78, s. 204-205. 
kuje już od pierwszych sekund projekcji ikoniczną przemocą odartą ze słów. Ma to jeszcze jeden wydźwięk, bowiem może służyć za pewnego rodzaju wentyl bezpieczeństwa. Otóż zrównanie dramatu żony Tadeusza i Róży zrównuje także Polkę i Mazurkę, a więc nie sytuuje losu Innej jako dominującej narracji, przez co twórca filmu nie naraża się na głosy krytyki ze strony publiczności przyzwyczajonej do centralnej pozycji cierpiącego Polaka. Smarzowski, mimo użycia niezwykle drastycznej, naturalistycznej formy, w wymiarze treściowym - odsłaniającym tabu, podąża bardzo zachowawczą ścieżką. Co więcej, zgodę z powszechnie akceptowanym modelem opowiadania o polskiej historii uzyskuje także poprzez utrwalenie heroicznego mitu w postaci Tadeusza.

Tadeusz stara się uchronić Różę przed losem, który spotkał jego żonę (wydarzenie otwierające film ma ogromny wpływ na zachowanie protagonisty), ale w depresyjnym filmie Smarzowskiego nie uda mu się tego dokonać. Wielokrotne pokazywanie seksualnej przemocy wobec kobiet (Róży, Amelki, żony Tadeusza, ale też wielu anonimowych kobiet) jest niezwykle mocne, naturalistycznie zobrazowane i nikogo nie pozostawia obojętnym. Oszczędne retrospekcje ukazują problem pamięci osób straumatyzowanych i choć są pokazywane obiektywizującym okiem kamery, to ujmują obrazy fragmentarycznie, w szczególności w scenie, kiedy córka Jadwiga, ukryta w kamienicy, patrzy na gwałconą matkę. Niemożność przyswojenia tego widoku przez bohaterkę widoczna jest w celowo chaotycznej konstrukcji filmowej. Montaż jest urywany, czas jakby pocięty, a muzyka drażni widza i rozdziera nawet somatycznie. Film udowadnia, że posiada środki, dzięki którym potrafi przedstawiać traumę, nierzadko niezwykle wiarygodnie przekazuje nam jej ślady, ale raczej nam jej nie zaszczepia. Jesteśmy w stanie zaangażować się emocjonalnie w tego typu przekaz (identyfikacja oparta na empatii), rozumiemy go, włączamy w nasze doświadczenie, ale oczywiście na tyle, na ile pozwala nam bezpieczna pozycja obserwatora świadomie obcującego z fikcją.

Julia Kristeva, w kontekście artykułowania przez sztukę traumatycznych przeżyć, używa stwierdzenia: „nadmiar obrazów i powściągnięcie słów”26, co znajduje idealne odzwierciedlenie w przedstawieniu głównej bohaterki filmu. Rola Agaty Kuleszy jest behawioralna, oparta przede wszystkim na milczeniu, aktorka jest skupiona na gestach i mimice ${ }^{27}$. Doświadczenie nie może zostać sprecyzowane w konkretnym miejscu i czasie, bowiem nadal trwa, a Róży nie będzie dane zdystansować się od przemocy, na jaką w gruncie rzeczy nadal jest narażona, mimo obecności Tadeusza. Alina Radny pisze, że przeżyta trauma często skutkuje ukryta przemoca skierowana do wewnątrz [...] Skutkuje też wycofaniem emocjonalnym i uczuciowym ofiary ${ }^{28}$, co idealnie oddaje postać zamkniętej w sobie Róży. Udziela ona tylko zdawkowych informacji, a kiedy ma opowiedzieć Tadeuszowi o przeszłości, która właściwie nadal trwa, nie znajduje słów, widzimy jej płacz i zaciśnięcie powiek. Po cięciu przenosimy się w retrospekcję. Róża nie potrafi mówić o gwałtach, bólu i strachu. Powraca tu ciągle powtarzane pytanie: jak o tym

26 J. Kristeva, Czarne stońce. Depresja i melancholia, przeł. M.P. Markowski, R. Ryziński, wstęp M.P. Markowski, Kraków 2007, s. 223, Horyzonty Nowoczesności, t. 63.

27 A. Morstin-Popławska, Mocne filmy..., s. 204-206.

28 A. Radny, Wptyw traumy na psychikę..., s. 110. 
rozmawiać, skoro brakuje figur reprezentacji? Róża staje się ofiarą, ponieważ jest Inna. Jest kobietą, której trudno bronić się samej, reprezentantką wykluczanej mniejszości etnicznej. Mało kto pamięta, że Mazurzy pruscy w XIX w. wcale nie czuli się Niemcami, posługiwali się własnym, odrębnym dialektem i zostali poddani przymusowej germanizacji. W roku 1945, po nowym wytyczeniu granic oraz przyznaniu zamieszkiwanego przez nich terytorium Polsce, przyczyniło się to do ich napiętnowania oraz wielu drastycznych konfliktów. Inność, żeby posłużyć się słowami Rudolfa Otta, budzi jednoczesną fascynację i grozę, ale w sytuacjach kryzysowych uwidacznia się aspekt grozy, co prowadzi do stygmatyzacji i finalnego wykluczenia ofiary.

Film porusza istotny problem historii marginalizowanej, ale postacie Tadeusza (cierpiącego później męki fizyczne podczas przesłuchania) i Róży Smarzowski ukazuje jako jednostki wyjątkowo czyste. Tadeusz, nawet jeśli dopuszcza się morderstw, to oczywiście robi to, by bronić słabszych, nie podejmuje współpracy z Urzędem Bezpieczeństwa i wraca najprawdopodobniej z łagru do Jadwigi - córki Róży, co sytuuje go w panteonie bohaterów bez skazy, wyjętych wprost z narracji typowych dla „fabryki snów”29. Odwraca to nieco uwagę widza od pobocznych wątków przedstawiających Polaków w wątpliwych moralnie postawach. Film utrwala i powiela heroiczny mit dzielnego akowca z powstania warszawskiego, przez co cały czas (od otwierającej sceny) widoczna jest prosta analogia między losem Mazurki i losem Polaków. Taka konstrukcja fabularna pozwala na choćby częściowe dojście do głosu marginalizowanej historii, czyli ujawnienie tabu. Przedstawiona opowieść nie jest jednak na tyle kontrowersyjna, żeby spotkać się ze sprzeciwem ze strony widowni, jak miało to miejsce przy znacznie bardziej prowokacyjnym Poktosiu.

\section{IDA - TRUDNA PRÓBA DIALOGU}

Zupełnie inną parę, tym razem bohaterek, stanowią tytułowa Ida oraz jej ciotka Wanda. Film Pawła Pawlikowskiego zdecydowanie bliższy jest Szkole Polskiej przede wszystkim poprzez specyficzny relatywizm i zastosowanie wysoce intelektualnej formy przekazu, bogatej w piętrzące się wizualne metafory. Fabuła opiera się na spotkaniu młodziutkiej nowicjuszki Anny (a właściwie Idy) z ciotką Wandą. Siostra przełożona sugeruje Idzie, aby przed przyjęciem święceń spotkała się z jedyną żyjącą krewną - siostrą jej matki, Wandą. Wanda wyjawia Annie jej prawdziwe imię i pochodzenie. Ida okazuje się Żydówką. Mamy tutaj do czynienia z dwiema postaciami, które reprezentują zupełnie inne światy wartości, ale też posiadają zupełnie inne doświadczenia życiowe. Wanda straciła całą swoją rodzinę, a po wojnie zaadaptowała się do nowych realiów politycznych i jako sędzia skazywała akowców na śmierć, stąd jej przydomek „krwawa Wanda”30. O Idzie możemy powiedzieć jedynie, że nie mówi za dużo, jej klasztorne wychowanie widać na każdym kroku. Choć są to zupełnie odmienne bohaterki, reżyser nigdy ich sobie nie

29 A. Morstin-Popławska, Mocne filmy..., s. 209.

30 Postać inspirowana prawdziwą stalinowską prokuratorką Heleną Wolińską-Brus. 
przeciwstawia, nigdy nie ocenia. Często nawet rezygnuje z frazy montażowej ujęcieprzeciwujęcie. Idę i Wandę przeważnie widzimy razem w jednym kadrze lub, rzadziej, w zestawieniu: zamiast naprzeciwko - obok siebie. Pawlikowski pokazuje dwie biografie: jedną ewidentnie traumatyczną, a drugą nieświadomą. Ida, powoli odkrywając swoją tożsamość, musi się zmierzyć z wszelkimi tego konsekwencjami. Protagonistki wyruszają w podróż do wsi Piaski obok Łomży, gdzie mieszkali Lebensteinowie, aby odkryć prawdę o losach rodziców Idy i syna Wandy. Okazuje się, że zostali oni zamordowani przez Polaków, którzy teraz mieszkają w ich domu. Wanda nie waha się używać wobec wszystkich informatorów ubeckich metod, ale widać w niej kobietę złamaną wewnętrznie. $\mathrm{Na}$ pozór twarda i oschła, pocieszenia szuka w ramionach obcych mężczyzn i w alkoholu, a w samotności przegląda zdjęcia bliskich, płacząc. Informacje o siostrze czy o synu wypowiada z trudnością, co znowu przywołuje problem z artykulacją słowną takich doświadczeń. Po odnalezieniu szczątków bliskich i pochowaniu ich Wanda popełnia samobójstwo, nie jest bowiem w stanie pogodzić się z poznaną prawdą i ogromem straty.

LaCapra za Freudem mówi, że pogodzenie się ze stratą może przyjąć albo bezpieczną formę wspomnienia, albo powracające wciąż, bardzo niepokojące trwanie w melancholii. Utrata, w przeciwieństwie do nieskonkretyzowanego braku, ma swoje podłoże w konkretnym miejscu i czasie, dlatego też nazywana jest „traumą historyczną"31. Spotkanie z Idą to dla Wandy szansa na przepracowanie traumy, odbycie żałoby (poprzez pogrzeb odnalezionych szczątków) i finalnie zamiana pustego miejsca na wspomnienie. Niestety, zachodzą tu dodatkowe okoliczności związane z wyrokami wydawanymi przez Wandę i prawdopodobnie uświadomienie jednoczesnej funkcji kata i ofiary. Postać byłej sędzi jest budowana z wielką dozą zrozumienia, a interpretacja jej postawy absolutnie nie jest jednoznaczna. Widzowi trudno jest ocenić postępowanie bohaterki, tym bardziej że nie osądza jej również milcząca Ida, która towarzyszy ciotce, ale jest wyłącznie niemą, bierną obserwatorką. Można nawet odnieść wrażenie, że główną bohaterką filmu jest Wanda, dopiero jej śmierć sprawia, że Ida w pewnym sensie budzi się z letargu i zaczyna próbować życia na zewnątrz klasztoru. W mieszkaniu ciotki zdejmuje habit i najpewniej po raz pierwszy pali papierosa, pije alkohol, zakłada elegancką sukienkę oraz buty na obcasie, by już jako kobieta wyjść na spotkanie z mężczyzną, który po spędzonej razem nocy proponuje jej wspólną przyszłość. Wszystkie te inicjacje pozwalają Idzie poznać inny świat, z którym nigdy wcześniej się nie zetknęła, ale mimo to w scenie finałowej dziewczyna wstaje z łóżka, wkłada habit i podąża własną drogą, najprawdopodobniej z powrotem do klasztoru, przyjąć święcenia.

Motyw drogi i wyborów jest w filmie bardzo silnie zaznaczony wizualnie. W kadrach zawsze pozostaje obok bohaterki duża przestrzeń, przeważnie nad jej głową. Zastanawiamy się, co może ona oznaczać. Coś wyższego? Może sumienie, może absolut, może Boga? W przestrzeni otaczającej Idę czasem pojawiają się związane ze sferą sacrum znaczące rekwizyty - krzyże, obrazy świętych, ale w otoczeniu Wandy widać jedynie pustkę. Wyjątek stanowi scena sądowa, gdzie nad głową Wandy wisi godło Polski Ludowej, oraz scena, w której była prokurator wykorzystuje stalinowskie metody przesłuchań na

31 Zob.: D. LaCapra, Trauma, Absence, Loss, „Critical Inquiry” 1999, Vol. 25, nr 4, s. 696-727. 
tle portretu świętej rodziny. Wykorzystanie symboliki chrześcijańskiej wywołało debatę wokół filmu. Krytyczki takie jak Agnieszka Graff' ${ }^{32}$ czy Anna Zawadzka ${ }^{33}$ sugerowały nawet, że Ida dokonuje chrystianizacji Zagłady. Ostro komentowały nadmierną estetyzację filmu, przez co rzekomo odnalezienie szczątków rodziców Idy ulega odpolitycznieniu ${ }^{34}$. Karolina Wigura również zauważa wątki chrześcijańskiej teologii w wymowie filmu, ale nie czyni z tego zarzutu. Autorka tłumaczy na łamach „Kultury Liberalnej”, że metaforyczne porównanie cierpienia Żydów z ofiarą ukrzyżowanego Chrystusa należy rozpatrywać raczej w kontekście wielkoniedzielnym - odrodzenia (zmartwychwstania) Idy jako Polki i Żydówki, odczytanego jako znak odrodzenia Wspólnoty ${ }^{35}$.

Pragnę jeszcze na chwilę powrócić do motywu drogi, rozumianego jako dokonywanie wyborów lub oczekiwanie na nie, ale i poszukiwanie prawdy o sobie, o własnej tożsamości. W filmie wyeksponowane są szosy, po których jadą bohaterki, ścieżki, po których podąża Ida, ale też schody, drzwi czy okna. Z okna rzuca się Wanda, a w następnej scenie widzimy w jej mieszkaniu Idę stojącą między otwartymi drzwiami, jakby nie wiedziała, jaką drogę wybrać. Oglądając tę scenę, zaczęłam ponownie zastanawiać się nad koncepcją postpamięci Marianne Hirsch, która zakłada, że kolejne pokolenia poprzez obcowanie $\mathrm{z}$ różnego typu przekazami są $\mathrm{w}$ stanie równie silnie odczuwać traumę, nie mając nawet bezpośredniej styczności z traumatycznym wydarzeniem ${ }^{36}$. Opowieść Wandy, pokazywane przez nią zdjęcia nieżyjącej rodziny czy historia Skiby (oprawcy rodziców) - to wszystko w zaproponowanej optyce nie jest tylko zapośredniczonym wspomnieniem, lecz zapośredniczonym (uwalnianym przez media postpamięci) pamięciowym śladem traumy, i podlegać musi przepracowaniu ${ }^{37}$. Pytanie brzmi jednak: czy brak dystansu czasowego w stosunku do objawionej prawdy o pochodzeniu i tożsamości Idy może być przepracowany poprzez szereg rytuałów inicjacyjnych? Czy Ida w ogóle doświadcza tej traumy, a właściwie posttraumy? Zakończenie jest otwarte, a ocenę zarówno Wandy, jak i Idy pozostawiono widzowi, ale czuć w filmie Pawlikowskiego chęć podjęcia dialogu: przybliżenia historii Żydów, przy użyciu kategorii w systemie myślenia chrześcijanina najbardziej poważnych, najsilniejszych ${ }^{38}$. Nie ma

32 Zob.: A. Graff, „Ida” - subtelność i polityka, „Krytyka Polityczna” 2013, 1 XI, [online] http:// www.krytykapolityczna.pl/artykuly/film/20131031/graff-ida-subtelnosc-i-polityka, 25 X 2013; H. Datner, A. Graff, My, komisarki od kultury - polemika z Varga o „Idzie”, Gazeta.pl, 13 XI 2013, [online] http://wyborcza.pl/1,75475,14939785,My_komisarki_od_kultury__polemika_z_Varga_ o__Idzie_.html, 25 X 2013.

33 Zob.: A. Zawadzka, Ida, Lewica.pl, 25 X 2013, [online] http://lewica.pl/blog/zawadzka/28791, 25 X 2013.

34 K. Wigura, Dlaczego „Ida” tak gniewa. Częściowe podsumowanie dyskusji o filmie Pawta Pawlikowskiego, „Kultura Liberalna” 2013, 26 XI, [online] http://kulturaliberalna.pl/2013/11/26/wigura-dlaczego-ida-tak-gniewa-czesciowe-podsumowanie-dyskusji-o-filmie-pawla-pawlikowskiego, 26 XI 2013.

35 Tamże.

36 M. Hirsch, Pokolenie postpamięci, przeł. M. Borowski, M. Sugiera, „Didaskalia” 2011, nr 105, s. 28-35.

37 A. Sierbińska, Konstrukcje pamięci. „Postpamięć” Marianne Hirsch, postpamięć Christiana Boltanskiego, „Konteksty” 2010, nr 1, s. 49.

38 K. Wigura, Dlaczego „Ida” tak gniewa... 
tu bohaterskich postaw, jak w przypadku Róży. Mamy Wandę, która jednak wpisuje się w stereotyp żydokomuny, ale mamy też Polaków, którzy zabili Lebensteinów i osiedli w ich domu. Fabuła nie jest skoncentrowana na jednowymiarowych, czystych postaciach. Wszystkie wydarzenia ukazane są relatywnie, dzięki czemu widz nie odnosi się negatywnie nawet do najbardziej ambiwalentnych momentów. Milcząca Ida należy do drugiego pokolenia, ale nie pragnie odwetu za krzywdy wyrządzone rodzinie. Pamięta, stara się zrozumieć, ale nikogo nie nienawidzi, bo nie tak została wychowana przez siostry zakonne. Można się spierać, czy przyjęcie w filmie dominującej optyki chrześcijańskiej było ze strony Pawlikowskiego zabiegiem właściwym. Najważniejsze jest to, że w Idzie zostaje podjęty dialog, który nie staje się „narracją zemsty”, ale spójną narracją o Polakach i Żydach pisaną w poszukiwaniu zrozumienia ${ }^{39}$.

\section{POKEOSIE - MOCNE UDERZENIE W KULTURĘ MILCZENIA}

Na koniec chciałabym krótko omówić film Poktosie, który w gruncie rzeczy odnosi się do problematyki poruszanej w Idzie, ale czyni to mniej subtelnie. Władysław Pasikowski o mordzie w Jedwabnem postanawia bowiem opowiedzieć w konwencji gatunkowej thrillera. Ryzykownie łączy reguły narracyjne kina gatunkowego z niesamowicie trudnym i haniebnym wycinkiem polskiej historii.

Akcja filmu toczy się w czasach współczesnych i rozpoczyna się od powrotu Franciszka Kaliny z USA. Mężczyzna po wielu latach emigracji przybywa do Polski na wieść o problemach brata - Józefa, który wszedł w ostry konflikt z niemalże całą wsią. Odkrył, że w okolicy znajduje się wiele żydowskich płyt nagrobnych, których mieszkańcy używali jako zwyczajnego materiału budowlanego. Józef, przekonany o niesłuszności takiego zachowania, zbiera porzucone płyty lub odkupuje je od sąsiadów za niemałe pieniądze, a na swoim polu tworzy z nich pewnego rodzaju cmentarzysko. Poszukiwanie żydowskich pomników staje się niemalże obsesją młodszego Kaliny. Franciszek początkowo sprzeciwia się działaniom brata, ponieważ nie widzi w nich żadnego sensu. Z jego perspektywy Żydzi to zapomniani obcy, którymi Józek nie powinien się interesować, ale kiedy dostrzega ze strony sąsiadów coraz większą niechęć, a nawet agresję, staje po stronie brata i postanawia wraz z nim poznać powód, dla którego wszyscy wokół milczą na temat zniknięcia mieszkających na tych terenach Żydów. Bracia wspólnie odkrywają, że poprzednich osadników w brutalny sposób zamordowali Polacy, chcący zagarnąć żydowskie ziemie, a wśród oprawców znajdował się także ojciec Kalinów. Wbrew woli mieszkańców wsi, na jaw wychodzi głęboko skrywana tajemnica. Największą karę za jej ujawnienie ponosi Józef, który zostaje ukrzyżowany na drzwiach stodoły, najprawdopodobniej przez rozwścieczonych sąsiadów. Jakkolwiek scena ukrzyżowania Kaliny na drzwiach stodoły nie byłaby utrwaleniem romantyczno-mesjanistycznych fantazmatów, to powtarza on historię wszystkich marginalizowanych, stając się ofiarą na ołtarzu historii.

39 Tamże. 
W Poktosiu mamy do czynienia z pamięcią, którą stworzyły fałszywe przekazy i kultura milczenia. Po zetknięciu z faktami (ujawnieniu prawdziwych sprawców morderstwa) nastąpiło agresywne wyparcie, tak samo widoczne w zachowaniu bohaterów w filmie, jak i w postawach widzów. Pewne grupy uznały ten film za antypolski, a kozłem ofiarnym uczyniły Macieja Stuhra - odtwórcę roli Józefa Kaliny. Okazało się, że przekaz wyrażający pamięć milczących wywołał tak wielką falę krytyki, że doprowadził do stygmatyzacji aktora, który odważył się bronić racji postaci, w którą się wcielił.

Na pierwszym pokazie prasowym Poktosia w finałowej scenie z ukrzyżowanym Józefem w ścieżce dźwiękowej słychać było słowa: „powiesił się - jak Judasz”, co czyni wymowę filmu jeszcze mocniejszą. W kopiach filmu, które były wyświetlane we wszystkich polskich kinach, ten fragment został usunięty. Z filmu wycięto wiele scen, które były zbyt dosadne dla widza, nieakceptującego takiej wersji historii.

Film Pasikowskiego wywołał największy skandal spośród dotąd omawianych. Spowodowały go przede wszystkim: ukazanie przemocy wobec ludności żydowskiej, umotywowanej wyłącznie chęcią wzbogacenia się; zaprezentowanie wstydliwego rozdziału historii wprost, bez żadnych usprawiedliwień; pragnienie utrzymania status quo „kultury milczenia" wyrażone w egzekucji Józka, który ośmielił się (tak naprawdę przypadkiem) ujawnić pamięć o poprzednich mieszkańcach poprzez ratowanie niszczejących nagrobków. Pasikowski pokazuje w Poktosiu niezaprzeczalną winę i odpowiedzialność Polaków za to, co wydarzyło się w Jedwabnem, ponadto odważa się zakwestionować ich heroizm oraz moralność, przez co wyrywa się z oswojonego sposobu opowiadania o wojnie. Udowadnia niestety, że prowadzona w PRL-u polityka wymazywania pamięci była niezwykle silna, skuteczna, a jej skutki zauważalne są do dziś.

\section{PODSUMOWANIE}

Dlaczego mimo tak silnych emocji związanych z ujawnianiem pewnych często niechlubnych kart historii kino nadal sięga do traumatycznych biografii? Tokarska-Bakir mówi o fetyszyzacji traumy, która staje się atrakcyjnym towarem, jest przejmowana przez fałszywe głosy, a co gorsza - nie pozwala na spokój i zapomnienie. Mach dodaje: traumatyczna biografia wraz z jej sensacyjna aura, staje sie towarem na sprzedaz $w$ dodatku bardzo pożądanym ${ }^{40}$, ale wyciąga inne wnioski. Różnego rodzaju formy sztuki pozwalają ocalić od zapomnienia, kiedy brakuje już pamiętających „prawdziwych ofiar”. Niekoniecznie wywołują u odbiorcy realne symptomy stresu pourazowego, każą mu przywłaszczać cudze narracje i trwać w melancholii. Przedstawianie tragicznych doświadczeń stanowi „chwytliwy” temat w dyskursie publicznym, ale jednocześnie spełnia postulat etyczny w duchu Levinasowskiej odpowiedzialności za Innego ${ }^{41}$. Może być tym, co LaCapra chciałby widzieć jako samoświadome poczucie wspólnoty polega-

A. Mach, Polska kondycja posttraumatyczna..., s. 220.

41

Tamże. 
jące na empatii ${ }^{42}$. Okazuje się, że coraz częściej porusza się stabuizowane wątki historii w Polsce oraz na świecie. Dowodem tego jest chociażby ogromna popularność i uznanie krytyki dla nagrodzonego Oscarem Zniewolonego w reżyserii Steve’a McQueena, w którym otwarcie porusza się problem niewolnictwa i rasizmu w Stanach Zjednoczonych. Wiadomo, że logika rynku niejako wymusza na twórcach sięganie po kontrowersyjne tematy, ale pozytywnym skutkiem jest odtajnianie i upowszechnianie marginalnych dotąd narracji. W pewnym stopniu pozwala to na realizację etycznych postulatów i nie stoi w sprzeczności z prawami, jakimi rządzi się kapitalizm.

Jeffrey K. Olick zadaje pytanie: dlaczego w życiu publicznym, zamiast skupić się na zmitologizowanej historii zwycięstw, przywołuje się dziś jej załamania i zgrzyty ${ }^{43}$ ? Według badacza, obecnie najpopularniejszą metodą legitymizacji władzy jest polityka żalu. Na gruncie nowoczesności, w której możliwe jest przedostanie się jednostkowych historii do świadomości zbiorowej, może ona powodować pewną etyczną odpowiedzialność. Przede wszystkim jest jednak stosowana w idealistycznym celu, aby kolejne pokolenia mogły swobodnie się porozumiewać, nie zamykając się w kategoriach katów i ofiar.

Konkluzją tych wszystkich poglądów może być głos Alison Landsberg wyrażający się w koncepcji „pamięci protetycznej”, która nie stanowi wyłącznie zindywidualizowanego doświadczenia, ale dzięki mediom (w tym dzięki filmowi) dostępna jest dla wszystkich uczestników kultury masowej ${ }^{44}$. Można spotkać wiele opinii, że powstawanie filmów o Zagładzie i w ogóle o trudnej tematyce historycznej skazane jest na spłycanie przekazu, kiczowatość, sprzyjanie gustom gawiedzi (przypadek Listy Schindlera), a co gorsza - przekłamywanie faktów. Fikcjonalne teksty kultury, nawet te inspirowane wydarzeniami autentycznymi, zawsze są w pewien sposób przetworzone, są komunikatami w mniejszym lub większym stopniu nacechowanymi ideologicznie, chociażby przez perspektywę samego twórcy. Owszem, mogą manipulować, pokazywać pars pro toto - pewien wycinek, który nie będzie reprezentacyjny, aczkolwiek z perspektywy przedstawionych przez mnie przykładów filmowych należy uznać, że budowanie za ich pomocą pamięci protetycznej przynosi także pozytywne efekty. Każdy z omówionych filmów wywołał publiczną debatę. Oczywiście im bardziej kontrowersyjnie ujęte było tabu, tym żywsza wynikała dyskusja, ale największą zaletą tej sytuacji było przeniknięcie marginalizowanej pamięci nielicznych do dyskursu powszechnego, a więc do pamięci zbiorowej. Ważna jest tu nie tylko identyfikacja z bohaterem podczas samego seansu, empatyczne zaangażowanie w jego traumatyczną biografię, ale także pozbawienie tej narracji statusu tabu dzięki medialnemu nagłośnieniu. Możliwe, że moja puenta jest nieco idealistyczna, ale mimo wielokrotnie sugerowanego tu nadania traumie rangi towaru widzę Różę, Idę i Poktosie jako ważny krok w budowaniu bardziej świadomej niż dotychczas pamięci zbiorowej.

42 A. Szczepan, Polski dyskurs posttraumatyczny..., s. 244-245.

43 M. Kobielska, Pamięć zbiorowa w centrum nowoczesności..., s. 188-193.

44 Zob.: A. Landsberg, Prosthetic Memory. The Transformation of American Remembrance in the Age of Mass Culture, New York 2004. 


\section{BIBLIOGRAFIA}

Datner H., Graff A., My, komisarki od kultury - polemika z Varga o „Idzie”, Wyborcza.pl, 13 XI 2013, [online] http://wyborcza.pl/1,75475,14939785,My_komisarki_od_kultury polemika_z_Varga_o_Idzie_html.

Farrell K., Post-Traumatic Culture. Injury and Interpretation in the Nineties, Baltimore 1998.

Graff A., „Ida” - subtelnoš́ i polityka, „Krytyka Polityczna” 2013, 1 XI, [online] http://www. krytykapolityczna.pl/artykuly/film/20131031/graff-ida-subtelnosc-i-polityka.

Hirsch M., The Generation of Postmemory. Writing and Visual Culture After the Holocaust, New York 2012, Gender and Culture.

Hirsch M., Pokolenie postpamięci, przeł. M. Borowski, M. Sugiera, „Didaskalia” 2011, nr 105.

Janion M., Niesamowita Stowiańszczyzna. Fantazmaty literatury, Kraków 2006.

Kobielska M., Pamięć zbiorowa w centrum nowoczesności. Ujęcie Jeffreya K. Olicka, „Teksty Drugie" 2010, nr 6.

Kristeva J., Czarne stońce. Depresja i melancholia, przeł. M.P. Markowski, R. Ryziński, wstęp M.P. Markowski, Kraków 2007, Horyzonty Nowoczesności, t. 63.

LaCapra D., Historia w okresie przejściowym. Doświadczenie, tożsamość, teoria krytyczna, przeł. K. Bojarska, Kraków 2009, Horyzonty Nowoczesności, t. 81.

LaCapra D., Trauma, Absence, Loss, „Critical Inquiry” 1999, Vol. 25, nr 4.

Landsberg A., Prosthetic Memory. The Transformation of American Remembrance in the Age of Mass Culture, New York 2004.

Lubelski T., Historia kina polskiego. Twórcy, filmy, konteksty, Katowice 2009.

Mach A., Poetyka postpamięci i etyka świadka-spadkobiercy Zagtady w polskiej literaturze najnowszej, Warszawa 2013 [maszynopis].

Mach A., Polska kondycja posttraumatyczna - próba diagnozy, [w:] Kultura po przejściach, osoby z przesztością. Polski dyskurs postzależnościowy - konteksty i perspektywy badawcze, red. R. Nycz, Kraków 2011, Seria Wydawnicza Centrum Badań Dyskursów Postzależnościowych, t. 1 .

Marczak M., Obraz Warmii i Mazur w polskim filmie fabularnym i serialu. Rekonesans, „Media Kultura -Komunikacja Społeczna" 2012, nr 8.

Mąka-Malatyńska K., Widok z tej strony. Przedstawienia Holocaustu w polskim filmie, Poznań 2012, Seria Filmoznawcza, nr 9.

Morstin-Popławska A., Mocne filmy i gtębokie kompleksy. „Róża” Wojtka Smarzowskiego wobec "Jak być kochanq" Wojciecha J. Hasa, „Kwartalnik Filmowy” 2012, nr 77/78.

Radny A., Wptyw traumy na psychikę. Psychoterapia ofiary, „Annales Academiae Medicae Stetinentis" 2011, sympozja 1: Neurokognitywistyka w patologii i zdrowiu 2009-2011.

Sierbińska A., Konstrukcje pamięci. „Postpamięć" Marianne Hirsch, postpamięć Christiana Boltanskiego, „Konteksty” 2010, nr 1.

Szczepan A., Polski dyskurs posttraumatyczny. Literatura polska ostatnich lat wobec Holokaustu i tożsamości żydowskiej, [w:] Kultura po przejściach, osoby z przesztością. Polski dyskurspostzależnościowy - konteksty i perspektywy badawcze, red. R. Nycz, Kraków 2011, Seria Wydawnicza Centrum Badań Dyskursów Postzależnościowych, t. 1. 
Tokarska-Bakir J., Polska jako chory cztowiek Europy? Jedwabne, „postpamięc’” i historycy, [online] http://www.eurozine.com/articles/2003-05-30-tokarska-pl.html.

Wigura K., Dlaczego „Ida” tak gniewa. Częściowe podsumowanie dyskusji o filmie Pawta Pawlikowskiego, „Kultura Liberalna” 2013, 26 XI, [online] http://kulturaliberalna.pl/2013/11/26/ wigura-dlaczego-ida-tak-gniewa-czesciowe-podsumowanie-dyskusji-o-filmie-pawla-pawlikowskiego.

Zawadzka A., Ida, Lewica.pl, 25 X 2013, [online] http://lewica.pl/blog/zawadzka/28791.

Katarzyna ŻAKIETA - absolwentka filologii polskiej oraz kulturoznawstwa na Uniwersytecie Łódzkim. Obecnie doktorantka w Katedrze Mediów i Kultury Audiowizualnej UŁ, gdzie przygotowuje dysertację na temat groteski w filmie współczesnym. Zajmuje się szeroko rozumianą kulturą popularną, kinem gatunków, fantastyką oraz estetyką kampu. Z pasją przygląda się także najnowszemu kinu polskiemu. Swoje artykuły publikowała m.in. w „Panoptikum” oraz „Ogrodach Nauk i Sztuk”. Jest organizatorką łódzkiego cyklu sesji naukowych „Spotkania z gatunkami”. 